\title{
Rachel Mairs. "New Discoveries of Documentary Texts from Bactria: Political and Cultural Change, Administrative Continuity"
}

\section{Gian Pietro Basello}

\section{(2) OpenEdition \\ 1 Journals}

\section{Electronic version}

URL: http://journals.openedition.org/abstractairanica/44751

DOI: 10.4000/abstractairanica.44751

ISBN: 1961-960X

ISSN: 1961-960X

Publisher:

CNRS (UMR 7528 Mondes iraniens et indiens), Éditions de l'IFRI

\section{Electronic reference}

Gian Pietro Basello, « Rachel Mairs. "New Discoveries of Documentary Texts from Bactria: Political and Cultural Change, Administrative Continuity" », Abstracta Iranica [Online], Volume 37-38-39 | 2018, document 10, Online since 30 December 2018, connection on 29 September 2020. URL : http:// journals.openedition.org/abstractairanica/44751; DOI : https://doi.org/10.4000/abstractairanica. 44751

This text was automatically generated on 29 September 2020.

Tous droits réservés 


\title{
Rachel Mairs. "New Discoveries of Documentary Texts from Bactria: Political and Cultural Change, Administrative Continuity"
}

\author{
Gian Pietro Basello
}

\section{REFERENCES}

Rachel Mairs. "New Discoveries of Documentary Texts from Bactria: Political and Cultural Change, Administrative Continuity" in Tomasz Derda, Adam Łajtar, Jakub Urbanik (eds.), in cooperation with Grzegorz Ochała, Andrzej Mirończuk. Proceedings of the 27th International Congress of Papyrology. Warsaw, 29 July - 3 August 2013 (= The Journal of Juristic Papyrology, Supplement 28). Warsaw, 2016, p. 2037-2061.

Mairs presents to a wide (not only papyrological) audience three major corpora of documentary texts from Bactria (present-day northern Afghanistan) in the Aramaic, Greek, and Bactrian languages published in the last two decades. The textual evidence, dating from the 5th century $\mathrm{BCE}$ to the 5th century $\mathrm{CE}$, allows us to 'trace the administrative history of Bactria through successive regime changes', from the Achaemenid province to an independent Graeco-Bactrian state and to the Kushan heartland. Synchronically, the Aramaic and Greek documents 'offer remarkable parallels with contemporary material from Egypt, and indicate that administrative (and scribal) practices at opposite ends of the Achaemenid and Hellenistic empire(s) had much in common'. Diachronically, the author emphasizes the continuity from the Achaemenid to the Hellenistic administrative practice, apparently left untouched by the political takeovers, suggesting a particular 'political and economic strategy' involving 'the retention of existing personnel and systems of economic production and exploitation in the service of a new political power'. The presented corpora are the Aramaic documents from Ancient Bactria in the Khalili collection published by J. NAVEH 
and S. SHAKED in 2012, the Greek inscriptions from Central Asia, especially those from $\mathrm{Ai}$ Khanoum (published as part of the Corpus Inscriptionum Iranicarum by G. Rougemont 2012 cf. AI 34-36, n¹5 G. Rougemont avec des contributions de Paul Bernard. Inscriptions grecques d'Iran et d'Asie centrale), and the legal and economic documents in Bactrian, an Iranian language written in Greek characters (published by N. Sims-Williams in 2000).

It could be marginally noted that the date of the Aramaic document $\mathrm{C} 1$ (in the Khalili collection, see p. 2042-2043) could be alternatively December 337-January 336 BCE, i.e. in the 1st year (after his accession year) of Artaxerxes IV instead of the 1st year (considered as corresponding to his accession year as suggested in other cases by L. Depuydt, JAOS, vol. 115, 1995, p. 193-204) of Artaxerxes V, who would be the same person addressed in the text as Bayasa, i.e. Bessos. It could not be the 1st year of Artaxerxes IV counted after his accession year because in the month Kislev of that year Bessos/Artaxerxes V was already dead.

\section{AUTHORS}

\section{GIAN PIETRO BASELLO}

Università degli Studi di Napoli “L'Orientale” 